\title{
Correction to: Translation, cultural adaptation and reproducibility of a Portuguese version of the Functional Index for Hand OsteoArthritis (FIHOA)
}

Francisco Vileimar Andrade de Azevedo ${ }^{1}$, Hermano Alexandre Lima Rocha ${ }^{2,3}$, Anamaria Jones ${ }^{4}$, Jamil Natour ${ }^{4}$ and Francisco Airton Castro da Rocha ${ }^{1,5^{*}}$

Correction to: Adv Rheumatol 61, 30 (2021)

https://doi.org/10.1186/s42358-021-00189-1

Following publication of the original article [1], an error was identified in the Acknowledgements section. The authors want to add the below statement:

We acknowledge the support we received from Dr. Emmanuel Maheu (Saint Antoine Hospital, Department of Rheumatology, Paris, France) that provided authorization for the translation and advice on the methods for our validation study.

The original article has been updated.

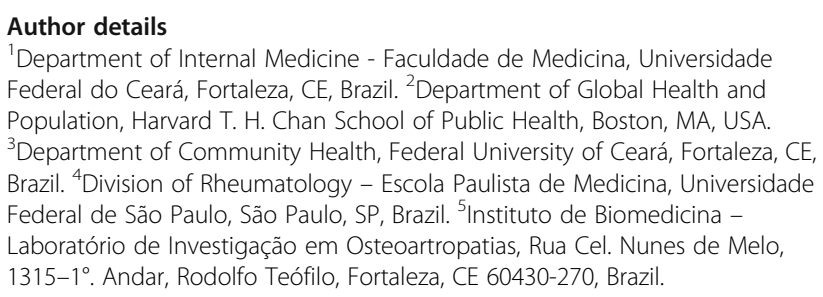

Published online: 22 June 2021

\section{Reference}

1. Azevedo, et al. Translation, cultural adaptation and reproducibility of a

Portuguese version of the Functional Index for Hand OsteoArthritis (FIHOA).

Adv Rheumatol. 2021;61:30. https://doi.org/10.1186/s42358-021-00189-1.

The original article can be found online at https://doi.org/10.1186/s42358021-00189-1.

*Correspondence: arocha@ufc.br

'Department of Internal Medicine - Faculdade de Medicina, Universidade Federal do Ceará, Fortaleza, CE, Brazil

${ }^{5}$ Instituto de Biomedicina - Laboratório de Investigação em Osteoartropatias, Rua Cel. Nunes de Melo, 1315-1. Andar, Rodolfo Teófilo, Fortaleza, CE 60430-270, Brazil

Full list of author information is available at the end of the article

() The Author(s). 2021 Open Access This article is licensed under a Creative Commons Attribution 4.0 International License, which permits use, sharing, adaptation, distribution and reproduction in any medium or format, as long as you give appropriate credit to the original author(s) and the source, provide a link to the Creative Commons licence, and indicate if changes were made. The images or other third party material in this article are included in the article's Creative Commons licence, unless indicated otherwise in a credit line to the material. If material is not included in the article's Creative Commons licence and your intended use is not permitted by statutory regulation or exceeds the permitted use, you will need to obtain permission directly from the copyright holder. To view a copy of this licence, visit http://creativecommons.org/licenses/by/4.0/ 